\title{
Trends and spatial shifts in lightning fires and smoke concentrations in response to 21st century climate over the national forests and parks of the western United States
}

\author{
Yang $\mathrm{Li}^{1}$, Loretta J. Mickley ${ }^{1}$, Pengfei Liu ${ }^{1}$, and Jed O. Kaplan ${ }^{2}$ \\ ${ }^{1}$ John A. Paulson School of Engineering and Applied Sciences, Harvard University, Cambridge, MA, USA \\ ${ }^{2}$ Department of Earth Sciences, The University of Hong Kong, Hong Kong, China
}

Correspondence: Yang Li (yangli@seas.harvard.edu)

Received: 27 January 2020 - Discussion started: 20 February 2020

Revised: 28 May 2020 - Accepted: 9 June 2020 - Published: 27 July 2020

\begin{abstract}
Almost USD 3 billion per year is appropriated for wildfire management on public land in the United States. Recent studies have suggested that ongoing climate change will lead to warmer and drier conditions in the western United States, with a consequent increase in the number and size of wildfires, yet large uncertainty exists in these projections. To assess the influence of future changes in climate and land cover on lightning-caused wildfires in the national forests and parks of the western United States and the consequences of these fires on air quality, we link a dynamic vegetation model that includes a process-based representation of fire (LPJ-LMfire) to a global chemical transport model (GEOS-Chem). Under a scenario of moderate future climate change (RCP4.5), increasing lightning-caused wildfire enhances the burden of smoke fine particulate matter (PM), with mass concentration increases of $\sim 53 \%$ by the late 21 st century during the fire season in the national forests and parks of the western United States. In a high-emissions scenario (RCP8.5), smoke PM concentrations double by 2100 . RCP8.5 also shows enhanced lightning-caused fire activity, especially over forests in the northern states.
\end{abstract}

\section{Introduction}

Both the incidence and duration of large wildfires in the forests of the western United States have increased since the mid-1980s (Westerling et al., 2006; Abatzoglou and Williams, 2016), affecting surface levels of particulate matter (Val Martin et al., 2006, 2015), with consequences for hu- man health (Liu et al., 2017) and visibility (Spracklen et al., 2009; Ford et al., 2018). Wildfire activity is influenced by a combination of different factors, including fuel load, fire suppression practices, land use, land cover change, and meteorology (Pechony and Shindell, 2010). Over the forests of the western United States (WUS), lightning-caused wildfires account for the majority of burned area (Abatzoglou et al., 2016; Brey et al., 2018) and have driven most of the recent increase in large wildfires, with human ignition contributing less than $12 \%$ to this trend (Westerling, 2016). Studies suggest that a warming climate could enhance wildfires in the WUS (Yue et al., 2013; Abatzoglou and Williams, 2016), but quantifying future wildfire activity is challenging, given the uncertainties in land cover trends and in the relationships between fire and weather. Not all of these studies that attempt to predict future fire activity have accounted for changing land cover or distinguished the effects of lightning fire ignitions from human-started fires. In this study, we project lightningcaused fire emissions and wildfire-specific particulate matter (PM) concentrations over the national forests and parks of the WUS in the middle and late 21 st century, using a dynamic global vegetation model combined with a chemical transport model. Our goal is to understand how trends in both land cover and meteorology may affect natural fire activity and smoke air quality over the 21 st century.

Consistent with projections of increasing wildfire in the WUS, recent studies have also predicted enhancement of firegenerated PM (smoke PM; BC + OC) under a warmer and drier climate in this region (Yue et al., 2013, 2014; Spracklen et al., 2009; Ford et al., 2018; Westerling et al., 2006). Some 
of these studies relied on statistical models that relate meteorological variables to fire metrics, such as area burned; these models can then be applied to projections from climate models (Yue et al., 2013, 2014; Spracklen et al., 2009; Archibald et al., 2009; Wotton et al., 2003; Westerling and Bryant, 2008). However, these statistical methods do not account for changes in vegetation due to climate, increasing atmospheric $\mathrm{CO}_{2}$ concentrations, or land use. A further weakness of these studies is that they do not consider whether enhanced fire activity in the future atmosphere may ultimately deplete the supply of woody fuels (Yue et al., 2013, 2014). Other studies have coupled global vegetation models to climate models to better represent such fire-vegetation-climate interactions (Chaste et al., 2018; Ford et al., 2018). Dynamic vegetation models with interactive fire modeling provide important estimates for long-term and large-scale changes in fire emissions, with most of these models simulating present-day fire emissions within the range of satellite products but failing to reproduce the interannual variability ( $\mathrm{Li}$ et al., 2019; Hamilton et al., 2018). The coupled modeling approaches integrate vegetation dynamics, land-atmosphere exchanges, and other key physical processes, allowing consideration of many factors driving fire activity and smoke pollution on regional scales. Building on this research, we use an integrated vegetation-climate model system with the aim of clarifying how changing meteorology and vegetation together drive future lightning-caused wildfire activity. We also provide predictions of smoke pollution at finer spatial resolution than previously available. Our approach accounts for the impact of future climate and lightning fires on fuel structure, and these fine-scale predictions are of greater utility to environmental managers and especially the health impacts community.

Lightning is the predominant cause of wildfire ignition in most mountainous and forest regions of the WUS during months that have high fire frequency (Abatzoglou et al., 2016; Balch et al., 2017). In remote and mountainous terrain, anthropogenic ignitions are infrequent and $>90 \%$ of total area burned is caused by lightning-started fires (Abatzoglou et al., 2016). Here we study lightning-caused fires over the national forests and parks of the WUS in the middle and late 21 st century under two future climate change scenarios defined by Representative Concentration Pathways (RCPs). RCP4.5 represents a moderate pathway with gradual reduction in greenhouse gas (GHG) emissions after 2050, while RCP8.5 assumes continued increases in GHGs throughout the 21 st century. We use the Lund-PotsdamJena-Lausanne-Mainz (LPJ-LMfire) Dynamic Global Vegetation Model (Pfeiffer et al., 2013) to simulate dynamic firevegetation interactions under future climate. LPJ-LMfire, which has been used previously to investigate historical fire activity (e.g., Chaste et al., 2018), is applied here to estimate natural fire emissions under future climate simulated by the Goddard Institute for Space Studies (GISS) Model E climate model. July, August, and September (JAS) are the months of greatest fire activity in WUS forests (Park et al., 2003) and are the focus of our study. We limit the spatial extent of our analyses to the national forests and parks of the WUS, here defined as $31-49^{\circ} \mathrm{N}, 100-125^{\circ} \mathrm{W}$.

\section{Methods}

We quantify the effects of changing climate on area burned and fire emissions caused by lightning over the national forests and parks in the WUS using the LPJ-LMfire model (Pfeiffer et al., 2013), driven by meteorological fields from the GISS-E2-R climate model (Nazarenko et al., 2015). Combined with emission factors from Akagi et al. (2011), dry matter burned calculated by LPJ-LMfire can be used to estimate natural wildfire emissions of black carbon (BC) and organic carbon (OC) particles, which are then passed to GEOS-Chem, a 3-D chemical transport model, to simulate the transport and distribution of wildfire smoke across the WUS. A flowchart of the modeling setup is included in the Supplement (Fig. S1).

\subsection{LPJ-LMfire}

The LPJ-LMfire dynamic vegetation model is driven by gridded climate, soil, land use fields, and atmospheric $\mathrm{CO}_{2}$ concentrations and simulates vegetation structure, biogeochemical cycling, and wildfire (Pfeiffer et al., 2013; Sitch et al., 2003). Wildfires are simulated based on processes including explicit calculation of lightning ignitions, the representation of multiday burning and coalescence of fires, and the calculation of rates of spread in different vegetation types (Pfeiffer et al., 2013). LPJ-LMfire calculates fire starts as a function of lightning ground strikes and ignition efficiency. Not every lightning strike causes fire. The model accounts for the flammability of different plant types, fuel moisture, the spatial autocorrelation of lightning strikes, and previously burned area. As fires grow in size, the likelihood of fire coalescence or merging increases. Fires are extinguished by consuming the available fuel or by experiencing sustained precipitation (Pfeiffer et al., 2013). Our study does not consider changes in human-caused fires, including agricultural fires.

The climate anomaly fields from the GISS-E2-R climate model used to prepare a future scenario for LPJ-LMfire are monthly mean surface temperature, diurnal temperature range (i.e., the difference between monthly mean daily maximum and daily minimum temperatures), total monthly precipitation, number of days in the month with precipitation greater than $0.1 \mathrm{~mm}$, monthly mean total cloud cover fraction, and monthly mean surface wind speed. This version of the GISS model was configured for Phase 5 of the Coupled Model Intercomparison Project (CMIP5) (Nazarenko et al., 2015). For RCP4.5, the GISS model predicts a statistically significant increase in surface temperature of $1.4 \mathrm{~K}$ averaged over the entire region by 2050 during JAS; for RCP8.5, the 
mean JAS temperature increase is $3.7 \mathrm{~K}$ by 2100 . In both future climate scenarios, significant precipitation decreases of $\sim 20 \%$ by 2100 are simulated. Several studies have predicted future increases in lightning due to climate change (e.g., Price and Rind, 1994a; Romps et al., 2014). However, the relationship between lightning flash rate and meteorology is poorly constrained in models and depends largely on physical parameters such as cold cloud thickness, cloud top height, or convective available potential energy. In our study, lightning strike density for application in LPJ-LMfire is calculated using the GISS convective mass flux following the empirical parameterization of Magi (2015). Although observations suggest a link between aerosol load and lightning frequency (e.g., Altaratz et al., 2017), we do not consider that relationship here. Unlike surface temperature and precipitation, we find that average lightning density over the WUS does not change significantly during the 21 st century, as described in Fig. S2. LPJ-LMfire scales lightning flashes to cloud-to-ground lightning strikes, which are the portion of total flashes in clouds that directly causes natural wildfires (Pfeiffer et al., 2013). Therefore, cloud-to-ground lightning frequencies are also considered constant during the 21 st century. We run LPJ-LMfire on a $0.5^{\circ} \times 0.5^{\circ}$ global grid, though for this study only results over the national forests and parks of the WUS are analyzed.

The GISS-E2-R meteorology used here covers the period 1701-2100 at a resolution of $2^{\circ}$ latitude $\times 2.5^{\circ}$ longitude. The start year of the two climate scenarios, RCP4.5 and $\mathrm{RCP} 8.5$, is 2006. The two RCPs capture a range of possible climate trajectories over the 21 st century, with radiative forcings at 2100 relative to pre-industrial values of $+4.5 \mathrm{~W} \mathrm{~m}^{-2}$ for RCP4.5 and $+8.5 \mathrm{~W} \mathrm{~m}^{-2}$ for RCP8.5. From 2011 to 2015 , the greenhouse gas concentrations of the two scenarios are nearly identical. To downscale the GISS meteorological fields to finer resolution for LPJ-LMfire, we first calculate the 2010-2100 monthly anomalies relative to the average over the 1961-1990 period and then add the resulting time series to a high-resolution observationally based climatology at $0.5^{\circ}$ latitude $\times 0.5^{\circ}$ longitude spatial resolution. The climatology was prepared using the datasets, including WorldClim 2.1, Climate WNA, CRU CL 2.0, Wisconsin HIRS Cloud Climatology, and LIS/OTD, as described in Pfeiffer et al. (2013). For each RCP, LPJ-LMfire simulates vegetation dynamics and fire continuously for the period 1701-2100, with monthly resolution. Continuous 400 -year simulations allow for sufficient spin-up. The LPJ-LMfire simulations used here cover the period 2006-2100. We apply future land use scenarios following the two RCPs in CMIP5, in which the extent of crop and pasture cover in the WUS increases by $30 \%$ in future climates, with most of these changes occurring outside the national forest and park lands in the region (Brovkin et al., 2013; Kumar et al., 2013).

Passive fire suppression results from landscape fragmentation caused by land use (e.g., for crop and grazing land, roads, and urban areas), and this influence on fire activity is included in the LPJ-LMfire simulations (Pfeiffer et al., 2013). The model does not, however, consider the active fire suppression practiced throughout much of the WUS. We therefore limit our study to wildfire activity on the national forest and park lands of the WUS that are dominated by lightning fires and where land use for agriculture and urban areas is minimal. To focus only on national forest and park lands, we apply a $0.5^{\circ} \times 0.5^{\circ}$ raster across the WUS that identifies the fraction of each grid cell that belongs to a national forest or national park (Fig. S3), and we consider only these areas in our analysis. To calculate fire emissions, we multiply the simulated dry matter burned by the fraction of national forest or park within each grid cell.

\subsection{Fire emissions}

Fuel biomass in LPJ-LMfire is discretized by plant functional type (PFT) into specific live biomass and litter categories, and across four size classes for dead fuels. The model simulates monthly values of total dry matter burned for nine PFTs, as in Pfeiffer et al. (2013). To pass LPJ-LMfire biomass burning emissions to GEOS-Chem, we first reclassify these nine PFTs into the six land cover types considered by GEOS-Chem. See Table S1 in the Supplement for a summary of the reclassification scheme. Tropical broadleaf evergreen, tropical broadleaf raingreen, and $\mathrm{C}_{4}$ grasses are not simulated by LPJ-LMfire in the national forests and parks of the WUS. Emission factors based on the six land cover types in GEOS-Chem are then applied to dry matter burned from LPJ-LMfire, resulting in monthly $\mathrm{BC}$ and $\mathrm{OC}$ emissions over national forests and parks. These factors are from Akagi et al. (2011). As lightning-started wildfires are dominant over the WUS forests, an evaluation of fire emissions over national forest and park lands from the LPJ-LMfire model against the Global Fire Emissions Database (GFED4s) inventory (Giglio et al., 2013) is included in the Supplement (Fig. S4).

\subsection{GEOS-Chem}

We use the GEOS-Chem chemical transport model (version 12.0.1; http://acmg.seas.harvard.edu/geos/, last access: 17 July 2020). We first carry out a global simulation at $4^{\circ}$ latitude $\times 5^{\circ}$ longitude spatial resolution and then downscale to $0.5^{\circ} \times 0.625^{\circ}$ over the WUS via grid nesting over the North America domain. For computational efficiency, we use the aerosol-only version of GEOS-Chem, with monthly mean oxidants archived from a full-chemistry simulation, as described in Park et al. (2004). Simulations with the fine-scale GEOS-Chem are computationally expensive, and we first test whether performing 5-year simulations will adequately capture the interannual variability in fire activity generated by the LPJ-LMfire model. We take the average of fire season total dry matter burned over 5 -year time slices in different periods across the 21st century and find that these averages differ from the same quantity averaged over 10-year time slices 
by less than $20 \%$, which is much less than the discrepancies caused by using different climate models in future predictions (Sheffield et al., 2013). This relatively small difference gives us confidence that 5-year simulations in GEOSChem will suffice for this study. We therefore perform two 5 -year time slice simulations for each RCP, covering the present day (2011-2015) and the late 21st century (20962100). The GEOS-Chem simulations are driven with presentday MERRA-2 reanalysis meteorology from NASA/GMAO (Gelaro et al., 2017) to isolate the effect of changing wildfires on US air quality. The simulations include emissions of all primary PM and the gas-phase precursors to secondary particles, with non-fire particle sources comprising fossil fuel combustion from transportation, industry, and power plants from the 2011 EPA NEI inventory. In the future time slices, non-fire emissions remain fixed at present-day levels.

Our study focuses on carbonaceous PM (smoke PM; BC+ OC), which are the main components in wildfire smoke (Chow et al., 2011). For the present day, we apply 5-yearaveraged (2011-2015) GFED4s emissions to those regions that fall outside national forests and parks and temporally changing LPJ-LMfire emissions from the two RCPs within the forests. Implementing the combined emissions allows us to further validate the simulated results in this study using observations from the Interagency Monitoring of Protected Visual Environments (IMPROVE) network (Figs. S5 and S6). For the future time slices, we assume that fires outside national forests and parks remain at present-day levels, and we again combine the 2011-2015 GFED4s fire emissions with the temporally changing future LPJ-LMfire emissions over the national forests and parks.

\section{Results}

\subsection{Spatial shifts in fire activity}

Under both RCPs, 21st century climate change and increasing atmospheric $\mathrm{CO}_{2}$ concentrations lead to shifts in the distribution of total living biomass and dry matter burned. Figure 1 shows the changes in monthly mean temperature and precipitation averaged zonally over grid cells at each $1^{\circ}$ latitude of the WUS, relative to the present day, defined as $\sim 2010$. Peak temperature enhancements in JAS occur between $36-42^{\circ} \mathrm{N}$ for $\sim 2050$ and $\sim 2100$ in both RCPs, with a maximum enhancement of $4{ }^{\circ} \mathrm{C}$ for RCP 4.5 and $6{ }^{\circ} \mathrm{C}$ for RCP8.5 in 2100. Significant decreases in JAS precipitation occur between $33-45^{\circ} \mathrm{N}$ under RCP4.5 and at latitudes north of $39^{\circ} \mathrm{N}$ under RCP8.5 for $\sim 2100$. The maximum decrease in monthly precipitation over the WUS is $\sim 40 \mathrm{~kg} \mathrm{~m}^{-2}$ $(\sim 60 \%)$ in JAS under both RCPs. These warmer and drier conditions favor fire activity under future climate.

Fires and smoke production are dependent on fuel load, and throughout the 21 st century, total living biomass in the WUS is primarily concentrated in northern forests (Fig. 2).
For RCP4.5, living biomass exhibits significant enhancements in US national forests and parks at latitudes north of $43^{\circ} \mathrm{N}$ in the 2050 time slice and north of $45^{\circ} \mathrm{N}$ in the 2100 time slice. North of $46^{\circ} \mathrm{N}$, the change in living biomass at $2100\left(\sim 0.4 \mathrm{~kg} \mathrm{C} \mathrm{m}^{-2}\right)$ is double that at 2050 $\left(\sim 0.2 \mathrm{~kg} \mathrm{C} \mathrm{m}^{-2}\right)$. At latitudes south of $40^{\circ} \mathrm{N}$, living biomass in RCP4.5 is generally invariant over the 21 st century. In RCP8.5, living biomass also increases significantly near the Canadian border - e.g., as much as $\sim 0.2 \mathrm{~kg} \mathrm{Cm}^{-2}$ for the 2050 time slice and $\sim 0.4 \mathrm{~kg} \mathrm{Cm}^{-2}$ for the 2100 time slice, relative to the present day. In contrast, at latitudes between $42-47^{\circ} \mathrm{N}$ in RCP8.5, total living biomass decreases by as much as $-0.6 \mathrm{kgCm}^{-2}$ for $\sim 2100$. For both RCPs, these mid-century and late century changes in total living biomass are significant $(p<0.05)$ across nearly all latitudes. In RCP4.5, the spatial shifts of total living biomass are relatively weak from 2050 to 2100 , consistent with the moderate climate scenario with gradual reduction in greenhouse gas emissions after 2050. However, under the continuedemissions climate scenario RCP8.5, total living biomass in these forests first increases by 2050 and then decreases by $\sim 10 \%$ by 2100 , indicating a strongly disturbed vegetation system due to climate change. Despite this decrease, living biomass in this scenario is still abundant in the WUS in 2100 , especially over the northern forests (not shown), suggesting that future climate change will not limit fuel load for fire ignition or spread. Table 1 summarizes these results.

LPJ-LMfire simulates boreal needleleaf evergreen and boreal and temperate summergreen (broadleaf) trees as the dominant plant functional types (PFTs) in the national forests and parks of the WUS; these PFTs together account for $\sim 90 \%$ of the total biomass in our study domain. Changes over the 21st century (Fig. 2) reflect the changes in the growth and distribution of these PFTs, with increases in living biomass in the north and decreases in the south in both RCP scenarios (Fig. S7). In the 2100 time slice, vegetation shifts further north than in the 2050 time slice. The reasons for this shift can be traced to the climate regimes favored by different vegetation types, with temperate and boreal trees showing moderate to strong inclination in their growth along the north-south temperature gradient (Aitken et al., 2008). For example, the temperate broadleaf summergreen PFT favors regions with moderate mean annual temperatures and distinct warm and cool seasons (Jarvis and Leverenz, 1983), while boreal needleleaf evergreen generally occurs in colder climate regimes (Aerts, 1995). With rising temperatures, the living biomass of temperate summergreen trees increases in most states in the WUS, with maximum enhancement of $+1.0 \mathrm{~kg} \mathrm{C} \mathrm{m}^{-2}$ in western Washington, northern Montana, and Idaho by 2100 in RCP8.5 relative to 2010. Decreases in this vegetation type for this scenario occur in the south, as much as $-0.5 \mathrm{~kg} \mathrm{Cm}^{-2}$ in New Mexico. In contrast, boreal trees increase in only a few regions in the far north, with a substantial contraction in their abundance over much of the 
(a)

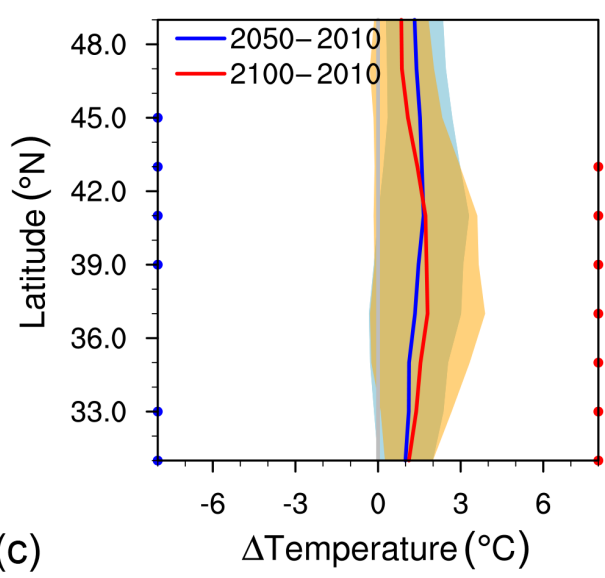

(c)

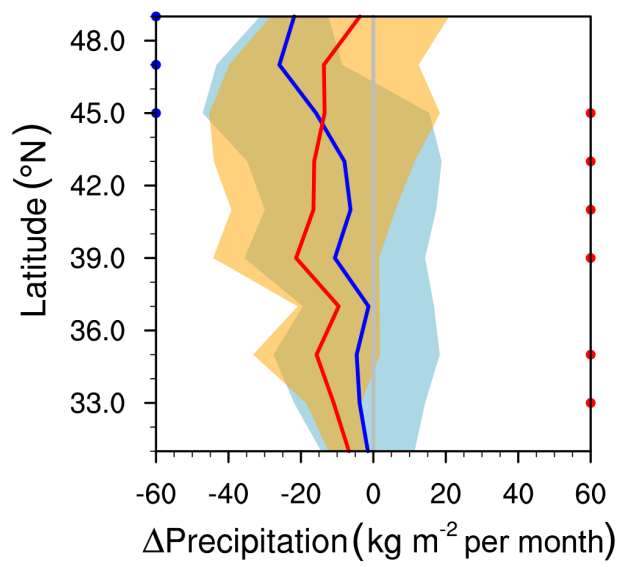

(b)
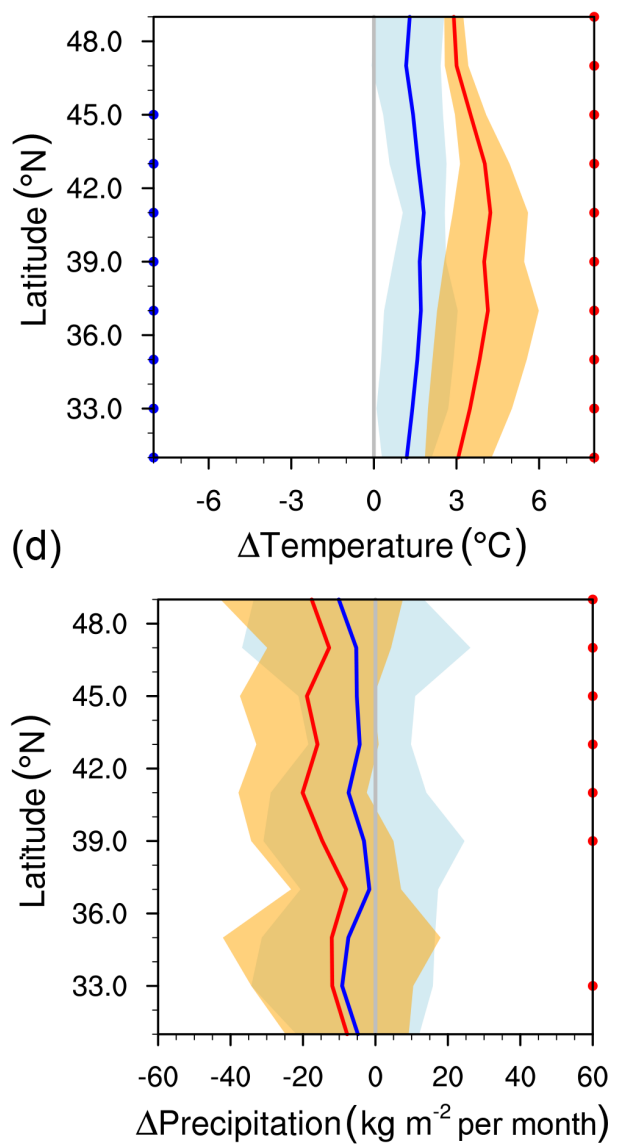

Figure 1. Modeled changes in temperature (a, b) and precipitation (c, d) in July-August-September (JAS) at $\sim 2050$ and $\sim 2100$ as a function of latitude over the WUS for RCP4.5 (a, c) and RCP8.5 (b, d) (Nadelhoffer et al., 1999). Changes are zonally averaged and relative to the present day $(\sim 2010)$, with 5-year averages in each time slice. The bold blue lines show the changes between 2010 and 2050 , averaged over all longitudes in the WUS $\left(31-49^{\circ} \mathrm{N}, 100-125^{\circ} \mathrm{W}\right)$; bold red lines show the mean changes between 2010 and 2100 . Light blue and orange shadings represent the temporal standard deviation across the 15 months ( 5 years $\times 3$ months) of each time slice. Blue dots along the axes mark those latitudes showing statistically significant differences between the JAS 2010 and 2050 time slices $(p<0.05)$; red dots mark those latitudes with statistically significant differences at 2100. Temperatures and precipitations are from the GISS-E2-R climate model.

Table 1. Total living biomass, dry matter burned (DM), and smoke PM $(\mathrm{BC}+\mathrm{OC})$ emissions over national forests and parks in the WUS and smoke PM concentrations averaged across the entire WUS. Values for the present day $(\sim 2010)$ are shown in the top row; changes in $\sim 2050$ and $\sim 2100$ relative to the present day are shown in bottom two rows. Statistically significant changes are in boldface.

\begin{tabular}{|c|c|c|c|c|c|c|c|c|}
\hline \multirow[t]{2}{*}{ Time slices } & \multicolumn{2}{|c|}{$\begin{array}{c}\text { Living biomass }^{\mathrm{b}} \text {, } \\
\mathrm{Tg} \mathrm{yr}^{-1}\end{array}$} & \multicolumn{2}{|c|}{$\begin{array}{c}\mathrm{DM}^{\mathrm{b}} \\
\text { Tg per month in JAS }\end{array}$} & \multicolumn{2}{|c|}{$\begin{array}{l}\mathrm{BC}+\mathrm{OC}_{\text {emission }}^{\mathrm{b}} \text {, } \\
\mathrm{Tg} \text { per month in JAS }\end{array}$} & \multicolumn{2}{|c|}{$\begin{array}{c}\mathrm{BC}+\mathrm{OC}^{\mathrm{c}}, \\
\mu \mathrm{g} \mathrm{m}^{-3}\end{array}$} \\
\hline & RCP4.5 & RCP8.5 & $\mathrm{RCP} 4.5$ & RCP8.5 & $\mathrm{RCP} 4.5$ & RCP8.5 & RCP4.5 & RCP8.5 \\
\hline $2010^{\mathrm{a}}$ & $074.8 \pm 33.7$ & $3036.9 \pm 55.5$ & $22.16 \pm 4.16$ & $30.96 \pm 7.15$ & $0.15 \pm 0.04$ & $0.21 \pm 0.06$ & $2.11 \pm 0.48$ & $2.55 \pm 0.81$ \\
\hline $2050-2010^{\mathrm{a}}$ & $138.2 \pm 46.0$ & $126.2 \pm 80.2$ & $18.0 \pm 16.1$ & $26.7 \pm 14.8$ & $0.15 \pm 0.13$ & $0.23 \pm 0.15$ & - & - \\
\hline $2100-2010^{\mathrm{a}}$ & $119.6 \pm 34.4$ & $-270.7 \pm 76.1$ & $24.6 \pm 13.2$ & $50.0 \pm 18.0$ & $0.18 \pm 0.14$ & $0.39 \pm 0.17$ & $1.11 \pm 1.02$ & $2.78 \pm 1.73$ \\
\hline
\end{tabular}

${ }^{a}$ Each time slice represents 5 years. ${ }^{b}$ Values are fire season summations over national forests and parks. ${ }^{\mathrm{c}} \mathrm{BC}+\mathrm{OC}$ concentrations are fire season averages over the WUS Statistical significance is not calculated for living biomass. 

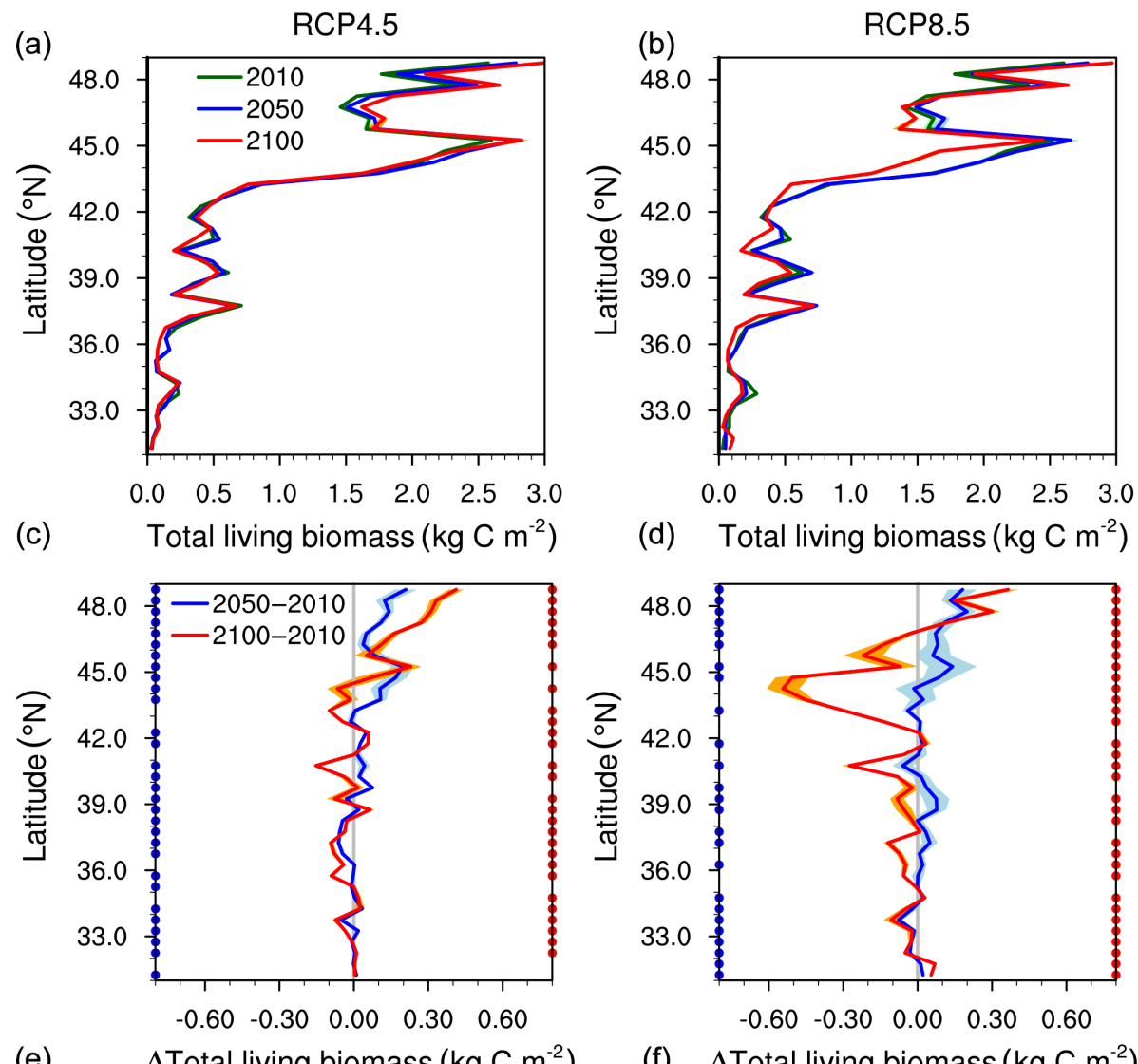

(e) $\quad \Delta$ Total living biomass $\left(\mathrm{kg} \mathrm{C} \mathrm{m}^{-2}\right)$
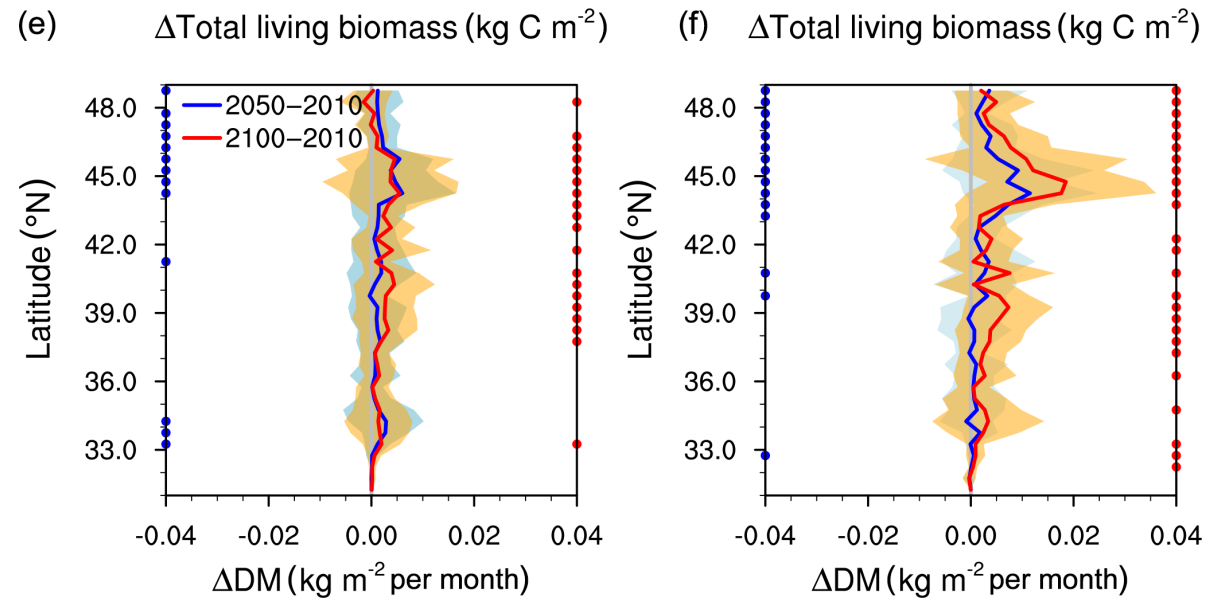

Figure 2. Panels (a, b) show total living biomass at $\sim 2010, \sim 2050$ and $\sim 2100$ as a function of latitude over the WUS for RCP4.5 and RCP8.5 (Nadelhoffer et al.), with 5-year averages in each time slice. Panels (c-f) are the same as in Fig. 1 but for changes in total living biomass (c, d) and lightning-caused dry matter burned (DM; e, f) as a function of latitude over the WUS. Results of living biomass and DM are from LPJ-LMfire. As in Fig. 1, dots along the axes mark those latitudes showing statistically significant differences.

WUS, as much as $-4.0 \mathrm{~kg} \mathrm{Cm}^{-2}$ for boreal needleleaf evergreen by 2100 in RCP8.5 over the northern forests.

Simulated area burned from lightning-ignited fires in the national forests and parks of the WUS increases by $\sim$ $30 \%$ by $\sim 2050$ and by $\sim 50 \%$ by $\sim 2100$ for both RCPs (not shown), comparable to the predicted $78 \%$ increase in lightning-caused area burned in the US under a doubled $\mathrm{CO}_{2}$ climate by Price and Rind (1994b), which did not account for vegetation changes due to climate change or changing $\mathrm{CO}_{2}$. That study, however, projected an increase in lightning flashes and did not consider changing land cover. The changes in area burned we calculate at 2050 are also within the range of previous studies using statistical methods for this region (e.g., 54\% in Spracklen et al., 2009 and 10\%$50 \%$ in Yue et al., 2013). Figure 2 further shows that dry matter burned, a function of both area burned and fuel load, 
increases relative to the present at most latitudes at both 2050 and 2100 and in both RCPs. Year-to-year variations in dry matter burned are greater than those in living biomass due to variations in the meteorological conditions driving fire occurrence. Previous studies have found that interannual variability in wildfire activity is strongly associated with regional surface temperature (Westerling et al., 2006; Yue et al., 2013). In our study, we show that total living biomass mostly decreases at latitudes $\sim 45^{\circ} \mathrm{N}$ by $\sim 2100$ under RCP8.5, but the peak enhancements in dry matter burned also occur at these latitudes. This finding indicates that the modeled changes in fire activity are driven by changes in meteorological conditions that favor fire, as well as by shifts towards more pyrophilic landscapes such as open woodlands and savannas. As with biomass, lighting-caused fires also shift northward over the 21st century, especially in RCP8.5. In this scenario, dry matter burned increases by as much as $35 \mathrm{~g} \mathrm{~m}^{-2}$ per month across $40-48^{\circ} \mathrm{N}$ at $\sim 2100$ compared to the present day. By 2100 , the fire season total dry matter burned over the forests in the WUS increases by $24.58 \mathrm{Tg}$ per month in JAS (111\%) under RCP4.5 and by 50.00 Tg per month in JAS (161\%) in RCP8.5 (Table 1).

The spatial distributions of changes in total living biomass and dry matter burned are shown in Fig. 3. Under RCP4.5, moderate decreases in total living biomass (by as much as $-2.5 \mathrm{~kg} \mathrm{C} \mathrm{m}^{-2}$ ) and increases in dry matter burned by 2100 (up to $\sim 70 \mathrm{~g} \mathrm{~m}^{-2}$ per month) are concentrated in central Idaho, Wyoming, and Colorado. Large declines in total living biomass and enhancements in dry matter burned occur in the forests of Idaho and Montana by 2100 under RCP8.5, with a hotspot of $-5.0 \mathrm{~kg} \mathrm{C} \mathrm{m}^{-2}$ in biomass and $+100 \mathrm{~g} \mathrm{~m}^{-2} \mathrm{mon}^{-1}$ in dry matter burned in Yellowstone National Park. Similar trends in total living biomass and dry matter burned are also predicted for the Sierra Nevada (SN) region in California (Fig. S8), with the region defined as in Yue et al. (2014). Predicted changes in dry matter burned over the SN forests by 2050 are $17 \%-44 \%$, comparable to the calculated future increases of $30 \%-50 \%$ by Yue et al. (2014). We find significant increases in dry matter burned of $81 \%$ by 2100 under RCP8.5 in the SN region. Our results suggest that even as future climate change diminishes vegetation biomass in some regions of the WUS, sufficient fuel still exists to allow increases in fire activity and dry matter burned.

\subsection{Smoke PM}

Given the large uncertainty in secondary aerosol formation within smoke plumes (Ortega et al., 2013), we assume that smoke PM mainly consists of primary BC and OC. We calculate emissions of fire-specific $\mathrm{BC}$ and $\mathrm{OC}$ by combining the estimates of the dry matter burned with emission factors from Akagi et al. (2011), which are dependent on land cover type. Application of these emissions to GEOS-Chem allows us to simulate the transport and distribution of smoke PM across the WUS.

With increasing lightning fire activity in most of the national forest and park areas of the WUS over the 21st century, smoke PM shows modest enhancement for RCP4.5 but more substantial increases for RCP8.5 (Fig. 4). Smoke PM enhancements in RCP4.5 occur primarily over the forests along the state boundaries of Idaho, Montana, and Wyoming, with large increases by as much as $\sim 10 \mu \mathrm{g} \mathrm{m}^{-3}$ in Yellowstone National Park. Scattered increases in smoke PM in RCP4.5 are also predicted over the forests in northern Colorado, northern California, western Oregon, and central Arizona. In RCP8.5, smoke PM enhancements are widespread over the northern states of the WUS by 2100 , with significant increases in regions east of the Rocky Mountains. Increased fire activity and large smoke PM enhancements are seen by 2100 in RCP8.5, including large areas of the Flathead (Montana), Nez Perce-Clearwater (Idaho), and Arapaho and Roosevelt (Colorado) National Forests. Particularly large increases - as much as $\sim 40 \mu \mathrm{g} \mathrm{m}^{-3}$ - occur in Yellowstone National Park (Wyoming). The increases in fire in these forests significantly influences air quality over the entire area of Idaho, Montana, Wyoming, and Colorado, with effects extending eastward to Nebraska and the Dakotas. Increased smoke PM is also predicted over the Sierra Nevada in both RCPs. In RCP4.5, average smoke PM over the entire WUS increases by $53 \%$ compared to present (Table 1). For RCP8.5, smoke PM more than doubles (109\% increase) at $\sim 2100$.

\section{Discussion}

We apply an offline, coupled modeling approach to investigate the impact of changes in climate and vegetation on future lightning-caused wildfires and smoke pollution across the national forests and parks of the WUS in the 21st century. The GISS model predicts a warmer and drier climate but nearly constant lightning frequency in both scenarios. For RCP4.5, the late 21st century lightning-caused wildfirespecific smoke PM in the national forests and parks of the WUS increases $\sim 53 \%$ relative to present. Comparable fire activity between 2050 and 2100 reflects the effectiveness of the emission reduction strategies after 2050 under RCP4.5, as temperature changes across the WUS are relatively flat from 2050 to 2100 , with a nearly constant area-averaged mean annual temperature of $\sim 19.2^{\circ} \mathrm{C}$. In RCP8.5, mean annual temperatures continue increasing over the second half of the 21 st century across the WUS, nearly $2.1^{\circ} \mathrm{C}$ from 2050 , and wildfire-specific PM concentrations double by 2100 . Increased fire activity is driven by changes in meteorological conditions that favor fire, as well as by shifts towards more pyrophilic landscapes such as open woodlands and savannas.

In Table 2 we compare predictions in this study with previous fire estimates under future climate. A difference between 

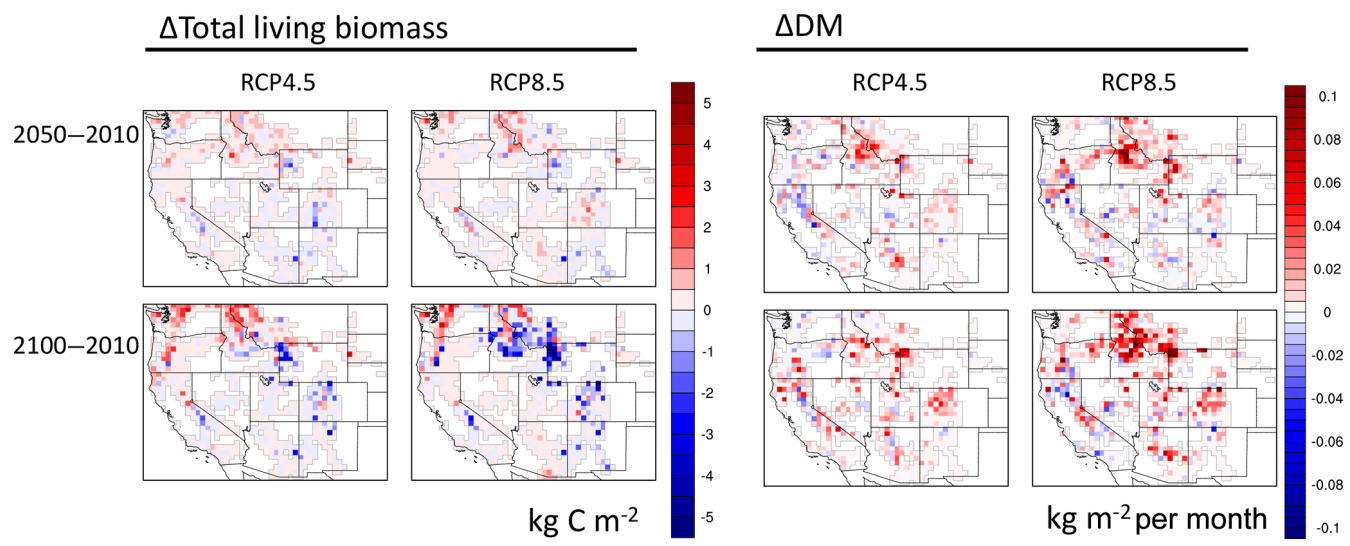

Figure 3. Simulated changes in yearly mean total living biomass and monthly mean DM averaged over the fire season in the national forests and parks across the WUS for the RCP4.5 and RCP8.5 scenarios. The top row shows changes between the present day and 2050, and the bottom row shows changes between the present day and 2100. Results are from LPJ-LMfire, with 5 years representing each time period. The fire season is July, August, and September. White spaces indicate areas outside the national forests and parks.

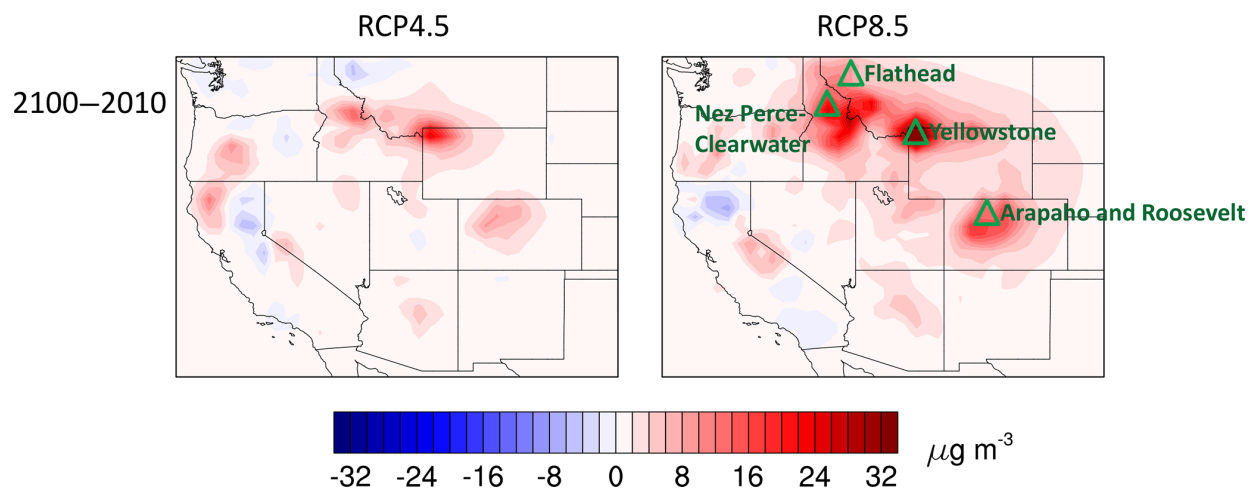

Figure 4. Simulated changes in fire season smoke PM $(\mathrm{BC}+\mathrm{OC})$ at $\sim 2100$ relative to the present day for RCP4.5 and RCP8.5. Results are from GEOS-Chem at a spatial resolution $0.5^{\circ} \times 0.625^{\circ}$, averaged over July, August, and September. Each time period is represented by a 5-year time slice. National parks and forests that experience large smoke PM enhancements are labeled by green triangles.

these studies and ours is that we consider only changes in fire activity over the national forests and parks while others examine changes over the whole WUS. However, we find that in the GFED4s inventory, present-day fire emissions outside these federally managed areas contribute less than $1 \%$ of total DM in the WUS. For area burned, the fraction outside national forests and parks could be higher than $1 \%$. In contrast, national forests and parks have abundant fuel supplies, making their fractional contribution to total DM much higher than would be implied by their fractional contribution to area burned. Also, the fact that lightning is the dominant driver of wildfire activity over the WUS forests (Balch et al., 2017) allows a reasonable comparison of the estimates in this study with those in previous studies that include both lightning and human-started fires over the WUS.

Table 2 shows that fire activity in the US is predicted to increase in all studies cited. However, the projected changes in fire metrics such as area burned or in emissions or concentrations of smoke vary greatly across studies, from $\sim 10 \%-$
$300 \%$ relative to present-day values. These discrepancies arise from differences in the methodologies, fire assumptions, future scenarios applied, domain and time period considered, and model resolution. The $\sim 80 \%$ increase in smoke emissions that we project by 2050 is generally lower than estimates in previous statistical studies (e.g., $150 \%-170 \%$ in Yue et al., 2013, or $100 \%$ in Spracklen et al., 2009). In contrast, the $\sim 80 \%$ increase in smoke emissions in this study at $\sim 2050$ is substantially higher than the $\sim 40 \%$ increases predicted by Ford et al. (2018) over the WUS, though the magnitudes of emission changes in the two studies are similar. As in our study, Ford et al. (2018) relied on a land cover model, but they also attempted to account for the influence of future changes in meteorology and population on the suppression and ignition of fires. Ford et al. (2018) predicted scattered emission increases of $40 \%-45 \%$ over the WUS and a large increase of $85 \%-220 \%$ over the southeastern United States due to increasing population and the role of human ignition. However, human activities have diverse impacts on wildfires, 
Table 2. Comparison of fire predictions in the US under future climate.

\begin{tabular}{|c|c|c|c|c|}
\hline Methods & $\begin{array}{l}\text { Region, scenarios, and fu- } \\
\text { ture time slice }\end{array}$ & $\begin{array}{l}\text { Fire metric and percent in- } \\
\text { crease } \\
\text { relative to present day }\end{array}$ & $\begin{array}{l}\text { Smoke PM and percent in- } \\
\text { crease } \\
\text { relative to present day }\end{array}$ & Reference \\
\hline $\begin{array}{l}\text { Statistical models for lightning } \\
\text { fires }\end{array}$ & $\begin{array}{l}\text { Entire US } \\
\text { Doubled } \mathrm{CO}_{2} \text { climate }\end{array}$ & $\begin{array}{l}\text { Number of fires: } 44 \% \\
\text { Area burned: } 78 \%\end{array}$ & & $\begin{array}{l}\text { Price and Rind } \\
(1994 b)\end{array}$ \\
\hline Two climate models & $\begin{array}{l}\text { Entire US } \\
\text { Doubled } \mathrm{CO}_{2} \text { climate } \\
\sim 2060\end{array}$ & $\begin{array}{l}\text { Seasonal fire severity rating: } \\
10 \%-50 \%\end{array}$ & & $\begin{array}{l}\text { Flannigan et al. } \\
(2000)\end{array}$ \\
\hline Statistical model & $\begin{array}{l}\text { California, US } \\
\text { A2 } \\
\sim 2100\end{array}$ & Large fire risk: $12 \%-53 \%$ & & $\begin{array}{l}\text { Westerling and } \\
\text { Bryant (2008) }\end{array}$ \\
\hline $\begin{array}{l}\text { Statistical models and GEOS- } \\
\text { Chem }\end{array}$ & $\begin{array}{l}\text { Western US } \\
\text { A1B } \\
\sim 2050\end{array}$ & $\begin{array}{l}\text { Area burned: } 54 \% \\
\text { Smoke emission: } 100 \%\end{array}$ & $\begin{array}{l}\text { Smoke PM concentrations } \\
\text { BC: } 20 \% \\
\text { OC: } 40 \%\end{array}$ & $\begin{array}{l}\text { Spracklen et al. } \\
(2009)\end{array}$ \\
\hline $\begin{array}{l}\text { Climate model with global- } \\
\text { scale fire parameterization }\end{array}$ & $\begin{array}{l}\text { Global } \\
\text { B1, A1B, A2 } \\
\sim 2100\end{array}$ & $\begin{array}{l}\text { Fire occurrence in the western } \\
\text { US } \\
\text { B1: } 120 \% \\
\text { A1B: } 233 \% \\
\text { A2: } 242 \%\end{array}$ & & $\begin{array}{l}\text { Pechony and Shin- } \\
\text { dell (2010) }\end{array}$ \\
\hline $\begin{array}{l}\text { MAPSS-CENTURY } 1 \text { dynamic } \\
\text { general vegetation model }\end{array}$ & $\begin{array}{l}\text { US Pacific Northwest } \\
\text { A2 } \\
\sim 2100\end{array}$ & $\begin{array}{l}\text { Area burned: } 76 \%-310 \% \\
\text { Burn severity: } 29 \%-41 \%\end{array}$ & & Rogers et al. (2011) \\
\hline $\begin{array}{l}\text { Statistical models }+ \text { GEOS- } \\
\text { Chem }\end{array}$ & $\begin{array}{l}\text { Western US } \\
\text { A1B } \\
\sim 2050\end{array}$ & $\begin{array}{l}\text { Area burned: } 63 \%-169 \% \\
\text { Smoke PM emissions: } 150 \%- \\
170 \%\end{array}$ & $\begin{array}{l}\text { Smoke PM concentrations: } \\
43 \%-55 \%\end{array}$ & Yue et al. (2013) \\
\hline Statistical models & $\begin{array}{l}\text { California, US } \\
\text { A1B } \\
\sim 2050\end{array}$ & Area burned: $10 \%-100 \%$ & & Yue et al. (2014) \\
\hline $\begin{array}{l}\text { Coupled Community Land } \\
\text { Model (CLMv4) and Com- } \\
\text { munity Earth System Model } \\
(\mathrm{CESM})^{\mathrm{b}}\end{array}$ & $\begin{array}{l}\text { Western US } \\
\text { RCP4.5 and RCP8.5 } \\
\sim 2050\end{array}$ & $\begin{array}{l}\text { Smoke PM emissions: } \\
\text { RCP4.5: } 100 \% \\
\text { RCP8.5: } 50 \%\end{array}$ & $\begin{array}{l}\text { Total } \mathrm{PM}_{2.5} \text { concentrations }^{\mathrm{a}} \\
\text { RCP4.5: } 22 \% \\
\text { RCP8.5: } 63 \%\end{array}$ & $\begin{array}{l}\text { Val Martin et al. } \\
(2015)\end{array}$ \\
\hline $\begin{array}{l}\text { CLMv4.5-BGC with fire pa- } \\
\text { rameterization coupled with } \\
\text { CESM }^{\mathrm{c}}\end{array}$ & $\begin{array}{l}\text { Contiguous US } \\
\text { RCP4.5 and RCP8.5 } \\
\sim 2050 \text { and } \sim 2100 \\
\text { Relative to the present day } \\
(1995-2005)\end{array}$ & $\begin{array}{l}\text { Area burned } \\
\text { by 2050: } \\
\text { RCP4.5: } 67 \% \\
\text { RCP8.5: } 50 \% \\
\text { by 2100: } \\
\text { RCP4.5: } 58 \% \\
\text { RCP8.5: } 108 \%\end{array}$ & $\begin{array}{l}\text { Total } \mathrm{PM}_{2.5} \text { concentrations } \\
\text { by } 2050: \\
\text { RCP4.5: } 146 \% \\
\text { RCP8.5: } 85 \% \\
\text { by 2100: } \\
\text { RCP4.5: } 108 \% \\
\text { RCP8.5: } 246 \%\end{array}$ & Pierce et al. (2017) \\
\hline $\begin{array}{l}\text { CLMv4.5 with fire parameteri- } \\
\text { zation coupled with } \mathrm{CESM}^{\mathrm{c}}\end{array}$ & $\begin{array}{l}\text { Contiguous US } \\
\text { RCP4.5 \& RCP8.5 } \\
\sim 2050 \text { and } \sim 2100 \\
\text { Relative to the present day } \\
(2000-2010)\end{array}$ & $\begin{array}{l}\text { Smoke PM emissions } \\
\text { by 2050: } \\
\text { RCP4.5: } 126 \% \\
\text { RCP8.5: } 54 \% \\
\text { by 2100: } \\
\text { RCP4.5: } 125 \% \\
\text { RCP8.5: } 149 \% \\
\text { by 2050 over the WUS: } \\
\text { RCP4.5: } 45 \% \\
\text { RCP8.5: } 40 \%\end{array}$ & $\begin{array}{l}\text { Total } \mathrm{PM}_{2.5} \text { concentrations } \\
\text { by } 2050: \\
\text { RCP4.5: } 113 \% \\
\text { RCP8.5: } 27 \% \\
\text { by 2100: } \\
\text { RCP4.5: } 93 \% \\
\text { RCP8.5: } 127 \%\end{array}$ & Ford et al. (2018) \\
\hline $\begin{array}{l}\text { LPJ-LMfire coupled with } \\
\text { GEOS-Chem }\end{array}$ & $\begin{array}{l}\text { Western US } \\
\text { RCP } 4.5 \text { and RCP8.5 } \\
\sim 2050 \text { and } \sim 2100 \\
\text { Relative to the present day } \\
(2011-2015)\end{array}$ & $\begin{array}{l}\text { Smoke PM emissions } \\
\text { by } 2050: \\
\text { RCP4.5: } 81 \% \\
\text { RCP8.5: } 86 \% \\
\text { by 2100: } \\
\text { RCP4.5: } 111 \% \\
\text { RCP8.5: } 161 \%\end{array}$ & $\begin{array}{l}\text { Smoke PM concentrations } \\
\text { by 2100: } \\
\text { RCP4.5: } 53 \% \\
\text { RCP8.5: } 109 \%\end{array}$ & This study \\
\hline
\end{tabular}

\footnotetext{
a Total $\mathrm{PM}_{2.5}$ is the combination of sulfate, ammonium nitrate, secondary organic aerosols, fine dust, fine sea salt, $\mathrm{BC}$, and $\mathrm{OC}$

$\mathrm{b}$ This model considers changes in climate, anthropogenic emissions, land cover, and land use.
}

c This model considers changes in climate, anthropogenic emissions, land cover, land use, and population. 
and those impacts are a function of land management policy, economics, and other social trends, making it challenging to predict how trends in human ignitions, fuel treatment, and fire suppression will evolve in the future (Fusco et al., 2016). In our study, we confine our focus to fires in national forests and parks in the WUS, where human activities, such as landscape fragmentation through land use, are less important. We further find that the patterns of increasing fire emissions by 2100 in our study - i.e., over the forests in northern Idaho, western Montana, and over the US Pacific Northwest - are similar to those predicted by other studies, including Rogers et al. (2011) and Ford et al. (2018). Our study also predicts significantly elevated smoke PM in Utah, Wyoming, and Colorado in the late 21st century under RCP8.5 and in regions east of the Rocky Mountains because of the prevailing westerly winds.

The following limitations apply to our study. The vegetation model simulations of biomass and fire are driven by meteorology from just one climate model, GISS-E2-R. Over the WUS, this model simulates future temperature changes at the low end of projections by the CMIP5 ensemble, making our predictions of future fire conservative (Sheffield et al., 2013; Ahlström et al., 2012; Rupp et al., 2013). Also, the GEOSChem simulations are driven with present-day MERRA-2 meteorology. Besides changes in fire emissions, future work could examine how changing meteorology may further influence smoke lifetime and transport processes and investigate the feedback of fire on meteorology by developing an online coupled modeling approach. Anthropogenic ignitions are not considered in this study, but fire behavior and therefore burned area simulated by LPJ-LMfire are primarily governed by meteorology and fuel structure. The fire simulations are performed on a $0.5^{\circ} \times 0.5^{\circ}$ grid, which cannot capture some the fine-grain structure of the complex topography and sharp ecotones present in our study area (e.g., Shafer et al., 2015). Our study also does not consider the effects of future climate change on the transport or lifetime of smoke PM or the feedback of smoke aerosols on regional climate. Previous work, however, has shown that climate effects on smoke PM are likely to be small relative to the effect of changing wildfire activity (Spracklen et al., 2009).

Within these limitations, our results highlight the vulnerability of the WUS to lightning-caused wildfire in a changing climate. Even though a changing climate decreases the living biomass in some regions, we find that ample vegetation exists to fuel increases in fire activity and smoke. Especially strong enhancements in smoke PM occur in the Northern Rockies in the late 21 st century under both the moderate and strong future emissions scenarios, suggesting that climate change will have a large, detrimental impact on air quality, visibility, and human health in a region valued for its national forests and parks. Our study thus provides a resource for environmental managers to better prepare for air quality challenges under a future climate change regime.
Data availability. Data related to this paper may be requested from the authors.

Supplement. The supplement related to this article is available online at: https://doi.org/10.5194/acp-20-8827-2020-supplement.

Author contributions. YL conceived and designed the study, performed the GEOS-Chem simulations, analyzed the data, and wrote the manuscript, with contributions from all coauthors. JOK performed the LPJ-LMfire simulations.

Competing interests. The authors declare that they have no conflict of interest.

Acknowledgements. We thank all of the data providers of the datasets used in this study. PM data were provided by the Interagency Monitoring of Protected Visual Environments (IMPROVE; available online at http://vista.cira.colostate.edu/improve, last access: 17 July 2020). IMPROVE is a collaborative association of state, tribal, and federal agencies and international partners. The U.S. Environmental Protection Agency is the primary funding source, with contracting and research support from the National Park Service. Jed Kaplan is grateful for access to computing resources provided by the School of Geography and the Environment, University of Oxford. The Air Quality Group at the University of California, Davis is the central analytical laboratory, with ion analysis provided by the Research Triangle Institute and carbon analysis provided by the Desert Research Institute. We acknowledge the World Climate Research Programme's Working Group on Coupled Modelling, which is responsible for CMIP, and we thank the group of NASA Goddard Institute for Space Studies for producing and making their GISS-E2-R climate model output available. For CMIP the U.S. Department of Energy's Program for Climate Model Diagnosis and Intercomparison provides coordinating support and led development of software infrastructure in partnership with the Global Organization for Earth System Science Portals. The GISS-E2-R dataset was downloaded from https://esgf-node.llnl.gov/search/cmip5/ (last access: 17 July 2020). We thank the Land use Harmonization team for producing the harmonized set of land use scenarios and making the dataset available online at http://tntcat.iiasa.ac.at/RcpDb/ (last access: 17 July 2020). We also thank $\mathrm{Xu}$ Yue for providing the raster of southern California.

Financial support. This research has been supported by the U.S. Environmental Protection Agency (grant nos. 83587501 and 83587201).

Review statement. This paper was edited by Dominick Spracklen and reviewed by Alan Wei Lun Lim and one anonymous referee. 


\section{References}

Abatzoglou, J. T., Kolden, C. A., Balch, J. K., and Bradley, B. A.: Controls on interannual variability in lightning-caused fire activity in the western US, Environ. Res. Lett., 11, 045005, https://doi.org/10.1088/1748-9326/11/4/045005, 2016.

Abatzoglou, J. T., and Williams, A. P.: Impact of anthropogenic climate change on wildfire across western US forests, P. Natl. Acad. Sci. USA, 113, 11770-11775, 2016.

Aerts, R.: The advantages of being evergreen, Trends Ecol. Evol., 10, 402-407, 1995.

Ahlström, A., Schurgers, G., Arneth, A., and Smith, B.: Robustness and uncertainty in terrestrial ecosystem carbon response to CMIP5 climate change projections, Environ. Res. Lett., 7, 044008, https://doi.org/10.1088/1748-9326/7/4/044008, 2012.

Aitken, S. N., Yeaman, S., Holliday, J. A., Wang, T., and Curtis-McLane, S.: Adaptation, migration or extirpation: climate change outcomes for tree populations, Evol. Appl., 1, 95-111, 2008

Akagi, S. K., Yokelson, R. J., Wiedinmyer, C., Alvarado, M. J., Reid, J. S., Karl, T., Crounse, J. D., and Wennberg, P. O.: Emission factors for open and domestic biomass burning for use in atmospheric models, Atmos. Chem. Phys., 11, 4039-4072, https://doi.org/10.5194/acp-11-4039-2011, 2011.

Altaratz, O., Kucienska, B., Kostinski, A., Raga, G. B., and Koren, I.: Global association of aerosol with flash density of intense lightning, Environ. Res. Lett., 12, 114037, https://doi.org/10.1088/1748-9326/aa922b, 2017.

Archibald, S., Roy, D. P., van Wilgen, B. W., and Scholes, R. J.: What limits fire? An examination of drivers of burnt area in Southern Africa, Glob. Change Biol., 15, 613-630, 2009.

Balch, J. K., Bradley, B. A., Abatzoglou, J. T., Nagy, R. C., Fusco, E. J., and Mahood, A. L.: Human-started wildfires expand the fire niche across the United States, P. Natl. Acad. Sci. USA, 114, 2946-2951, 2017.

Brey, S. J., Barnes, E. A., Pierce, J. R., Wiedinmyer, C., and Fischer, E. V.: Environmental conditions, ignition type, and air quality impacts of wildfires in the southeastern and western United States, Earth's Future, 6, 1442-1456, 2018.

Brovkin, V., Boysen, L., Arora, V., Boisier, J., Cadule, P., Chini, L., Claussen, M., Friedlingstein, P., Gayler, V., and Van Den Hurk, B.: Effect of anthropogenic land-use and land-cover changes on climate and land carbon storage in CMIP5 projections for the twenty-first century, J. Climate, 26, 6859-6881, 2013.

Chaste, E., Girardin, M. P., Kaplan, J. O., Portier, J., Bergeron, Y., and Hély, C.: The pyrogeography of eastern boreal Canada from 1901 to 2012 simulated with the LPJ-LMfire model, Biogeosciences, 15, 1273-1292, https://doi.org/10.5194/bg-15-12732018, 2018.

Chow, J. C., Watson, J. G., Lowenthal, D. H., Chen, L.-W. A., and Motallebi, N.: $\mathrm{PM}_{2.5}$ source profiles for black and organic carbon emission inventories, Atmos. Environ., 45, 5407-5414, 2011.

Flannigan, M. D., Stocks, B. J., and Wotton, B. M.: Climate change and forest fires, Sci. Total Environ., 262, 221-229, 2000.

Ford, B., Val Martin, M., Zelasky, S., Fischer, E., Anenberg, S., Heald, C., and Pierce, J.: Future fire impacts on smoke concentrations, visibility, and health in the contiguous United States, GeoHealth, 2, 229-247, 2018.
Fusco, E. J., Abatzoglou, J. T., Balch, J. K., Finn, J. T., and Bradley, B. A.: Quantifying the human influence on fire ignition across the western USA, Ecol. Appl., 26, 2390-2401, 2016.

Gelaro, R., McCarty, W., Suárez, M. J., Todling, R., Molod, A., Takacs, L., Randles, C. A., Darmenov, A., Bosilovich, M. G., and Reichle, R.: The modern-era retrospective analysis for research and applications, version 2 (MERRA-2), J. Climate, 30, 54195454, 2017.

Giglio, L., Randerson, J. T., and van der Werf, G. R.: Analysis of daily, monthly, and annual burned area using the fourthgeneration global fire emissions database (GFED4), J. Geophys. Res.-Biogeosci., 118, 317-328, 2013.

Hamilton, D. S., Hantson, S., Scott, C., Kaplan, J., Pringle, K., Nieradzik, L., Rap, A., Folberth, G., Spracklen, D., and Carslaw, K.: Reassessment of pre-industrial fire emissions strongly affects anthropogenic aerosol forcing, Nat. Commun., 9, 3182, https://doi.org/10.1038/s41467-018-05592-9, 2018.

Jarvis, P., and Leverenz, J.: Productivity of temperate, deciduous and evergreen forests, in: Physiological Plant Ecology IV. Encyclopedia of Plant Physiology (New Series), edited by: Lange, O. L., Nobel, P. S., Osmond, C. B., and Ziegler, H., D. Springer, Berlin, Heidelberg, 12, 233-280, 1983.

Kumar, S., Dirmeyer, P. A., Merwade, V., DelSole, T., Adams, J. M., and Niyogi, D.: Land use/cover change impacts in CMIP5 climate simulations: A new methodology and 21 st century challenges, J. Geophys. Res.-Atmos., 118, 6337-6353, 2013.

Li, F., Val Martin, M., Andreae, M. O., Arneth, A., Hantson, S., Kaiser, J. W., Lasslop, G., Yue, C., Bachelet, D., Forrest, M., Kluzek, E., Liu, X., Mangeon, S., Melton, J. R., Ward, D. S., Darmenov, A., Hickler, T., Ichoku, C., Magi, B. I., Sitch, S., van der Werf, G. R., Wiedinmyer, C., and Rabin, S. S.: Historical (17002012) global multi-model estimates of the fire emissions from the Fire Modeling Intercomparison Project (FireMIP), Atmos. Chem. Phys., 19, 12545-12567, https://doi.org/10.5194/acp-1912545-2019, 2019.

Liu, J. C., Wilson, A., Mickley, L. J., Dominici, F., Ebisu, K., Wang, Y., Sulprizio, M. P., Peng, R. D., Yue, X., and Son, J.-Y.: Wildfirespecific Fine Particulate Matter and Risk of Hospital Admissions in Urban and Rural Counties, Epidemiology, 28, 77-85, 2017.

Magi, B. I.: Global Lightning Parameterization from CMIP5 Climate Model Output, J. Atmos. Ocean. Technol., 32, 434-452, https://doi.org/10.1175/jtech-d-13-00261.1, 2015.

Nadelhoffer, K. J., Emmett, B. A., Gundersen, P., Kjønaas, O. J., Koopmans, C. J., Schleppi, P., Tietema, A., and Wright, R. F.: Nitrogen deposition makes a minor contribution to carbon sequestration in temperate forests, Nature, 398, 145-148, https://doi.org/10.1038/18205, 1999.

Nazarenko, L., Schmidt, G., Miller, R., Tausnev, N., Kelley, M., Ruedy, R., Russell, G., Aleinov, I., Bauer, M., and Bauer, S.: Future climate change under RCP emission scenarios with GISS ModelE2, J. Adv. Model. Earth Syst., 7, 244-267, 2015.

Ortega, A. M., Day, D. A., Cubison, M. J., Brune, W. H., Bon, D., de Gouw, J. A., and Jimenez, J. L.: Secondary organic aerosol formation and primary organic aerosol oxidation from biomassburning smoke in a flow reactor during FLAME-3, Atmos. Chem. Phys., 13, 11551-11571, https://doi.org/10.5194/acp-1311551-2013, 2013.

Park, R. J., Jacob, D. J., Chin, M., and Martin, R. V.: Sources of carbonaceous aerosols over the United States and impli- 
cations for natural visibility, J. Geophys. Res., 108, 4355, https://doi.org/10.1029/2002JD003190, 2003.

Park, R. J., Jacob, D. J., Field, B. D., Yantosca, R. M., and Chin, M.: Natural and transboundary pollution influences on sulfate-nitrate-ammonium aerosols in the United States: Implications for policy, J. Geophys. Res., 109, D15204, https://doi.org/10.1029/2003JD004473, 2004.

Pechony, O., and Shindell, D. T.: Driving forces of global wildfires over the past millennium and the forthcoming century, P. Natl. Acad. Sci. USA, 107, 19167-19170, 2010.

Pfeiffer, M., Spessa, A., and Kaplan, J. O.: A model for global biomass burning in preindustrial time: LPJ-LMfire (v1.0), Geosci. Model Dev., 6, 643-685, https://doi.org/10.5194/gmd-6643-2013, 2013.

Pierce, J., Val Martin, M., and Heald, C.: Estimating the effects of changing climate on fires and consequences for US air quality, using a set of global and regional climate models-Final report to the Joint Fire Science Program, Fort Collins (CO): Joint Fire Science Program, 2017.

Price, C. and Rind, D.: Possible implications of global climate change on global lightning distributions and frequencies, J. Geophys. Res.-Atmos., 99, 10823-10831, 1994a.

Price, C. and Rind, D.: The impact of a $2 \times \mathrm{CO}_{2}$ climate on lightning-caused fires, J. Clim., 7, 1484-1494, 1994 b.

Rogers, B. M., Neilson, R. P., Drapek, R., Lenihan, J. M., Wells, J. R., Bachelet, D., and Law, B. E.: Impacts of climate change on fire regimes and carbon stocks of the U.S. Pacific Northwest, J. Geophys. Res., 116, G03037, https://doi.org/10.1029/2011JG001695, 2011.

Romps, D. M., Seeley, J. T., Vollaro, D., and Molinari, J.: Projected increase in lightning strikes in the United States due to global warming, Science, 346, 851-854, 2014

Rupp, D. E., Abatzoglou, J. T., Hegewisch, K. C., and Mote, P. W.: Evaluation of CMIP5 20th century climate simulations for the Pacific Northwest USA, J. Geophys. Res.-Atmos., 118, 1088410906, 2013.

Shafer, S. L., Bartlein, P. J., Gray, E. M., and Pelltier, R. T.: Projected Future Vegetation Changes for the Northwest United States and Southwest Canada at a Fine Spatial Resolution Using a Dynamic Global Vegetation Model, PLoS One, 10, e0138759, https://doi.org/10.1371/journal.pone.0138759, 2015.

Sheffield, J., Barrett, A. P., Colle, B., Nelun Fernando, D., Fu, R., Geil, K. L., Hu, Q., Kinter, J., Kumar, S., and Langenbrunner, B.: North American climate in CMIP5 experiments. Part I: Evaluation of historical simulations of continental and regional climatology, J. Climate, 26, 9209-9245, 2013.
Sitch, S., Smith, B., Prentice, I. C., Arneth, A., Bondeau, A., Cramer, W., Kaplan, J. O., Levis, S., Lucht, W., Sykes, M. T., Thonicke, K., and Venevsky, S.: Evaluation of ecosystem dynamics, plant geography and terrestrial carbon cycling in the LPJ dynamic global vegetation model, Glob. Change Biol., 9, 161-185, https://doi.org/10.1046/j.1365-2486.2003.00569.x, 2003.

Spracklen, D. V., Mickley, L. J., Logan, J. A., Hudman, R. C., Yevich, R., Flannigan, M. D., and Westerling, A. L.: Impacts of climate change from 2000 to 2050 on wildfire activity and carbonaceous aerosol concentrations in the western United States, J. Geophys. Res., 114, D20301, https://doi.org/10.1029/2008JD010966, 2009.

Val Martin, M., Honrath, R., Owen, R. C., Pfister, G., Fialho, P., and Barata, F.: Significant enhancements of nitrogen oxides, black carbon, and ozone in the North Atlantic lower free troposphere resulting from North American boreal wildfires, J. Geophys. Res., 111, D23S60, https://doi.org/10.1029/2006JD007530, 2006.

Val Martin, M., Heald, C. L., Lamarque, J.-F., Tilmes, S., Emmons, L. K., and Schichtel, B. A.: How emissions, climate, and land use change will impact mid-century air quality over the United States: a focus on effects at national parks, Atmos. Chem. Phys., 15, 2805-2823, https://doi.org/10.5194/acp15-2805-2015, 2015.

Westerling, A., and Bryant, B.: Climate change and wildfire in California, Clim. Change, 87, 231-249, 2008.

Westerling, A. L., Hidalgo, H. G., Cayan, D. R., and Swetnam, T. W.: Warming and earlier spring increase western US forest wildfire activity, Science, 313, 940-943, 2006.

Westerling, A. L.: Increasing western US forest wildfire activity: sensitivity to changes in the timing of spring, Philos. T. Roy. Soc. B-Biol., 371, 20150178, https://doi.org/10.1098/rstb.2015.0178, 2016.

Wotton, B., Martell, D., and Logan, K.: Climate change and peoplecaused forest fire occurrence in Ontario, Clim. Change, 60, 275295, 2003.

Yue, X., Mickley, L. J., Logan, J. A., and Kaplan, J. O.: Ensemble projections of wildfire activity and carbonaceous aerosol concentrations over the western United States in the mid-21st century, Atmos. Environ., 77, 767-780, 2013.

Yue, X., Mickley, L. J., and Logan, J. A.: Projection of wildfire activity in southern California in the mid-twenty-first century, Clim. Dynam., 43, 1973-1991, 2014. 